\title{
Bones of Contention. Humanism, Translation, and Experience in Sixteenth-Century Translations of Galen's De ossibus
}

Il y a un os? Humanisme, traduction et expérience dans les traductions du De ossibus de Galien au seizième siècle

\section{R. Allen Shotwell}

\section{(2) OpenEdition}

\section{Journals}

Electronic version

URL: https://journals.openedition.org/aes/3838

DOI: $10.4000 /$ aes.3838

ISSN: 2258-093X

\section{Publisher}

Laboratoire LISAA

\section{Electronic reference}

R. Allen Shotwell, "Bones of Contention. Humanism, Translation, and Experience in Sixteenth-Century Translations of Galen's De ossibus", Arts et Savoirs [Online], 15 | 2021, Online since 25 June 2021, connection on 17 December 2021. URL: http://journals.openedition.org/aes/3838; DOI: https:// doi.org/10.4000/aes.3838

This text was automatically generated on 17 December 2021 .

Centre de recherche LISAA (Littératures SAvoirs et Arts) 


\title{
Bones of Contention. Humanism, Translation, and Experience in Sixteenth-Century Translations of Galen's De ossibus
}

\author{
Il y a un os? Humanisme, traduction et expérience dans les traductions du De \\ ossibus de Galien au seizième siècle
}

\section{R. Allen Shotwell}

1 Sixteenth-century editions of Galen's De ossibus ad tirones (On Bones for Beginners) play an interesting role in the development of Renaissance anatomy. Between 1535, when the first edition appeared, and the end of the sixteenth century, De ossibus was printed more than two dozen times in Latin, Greek, and French ${ }^{1}$. Along with De anatomicis administrationibus (On Anatomical Procedures), De ossibus represented the "new" anatomical knowledge from Galen translated into Latin and circulated in print for the first time in the sixteenth century, but the number of editions of On Anatomical Procedures pales in comparison to De ossibus. While conventional history of Renaissance medicine says that after about 1540, interest in Galen waned and new work and translations declined, editions of De ossibus increased after 1540, peaking in the 1550s but continuing to be strong through the end of the century and beyond. New translations were still being made as late as 1579, when Salomon Alberti printed his own Latin translation in Witteberg ${ }^{2}$.

2 In the years up to 1551, multiple editions of De ossibus were illustrated with an innovative image of the underside of the skull and two representations of skeletons that have received little attention in the history of early printed anatomical editions. After the appearance of Andreas Vesalius's De humani corporis fabrica in 1543, commentaries on De ossibus served as a vehicle for disputing or supporting the new Vesalian anatomy. Both trends had an effect on the popularity of the work, but as a short text written for an introductory audience, De ossibus was also useful for teaching purposes - which further contributed to its popularity. The following article takes a 
look at the contents of De ossibus, the various editions printed in the sixteenth century, the illustrated editions, and the commentaries written in response to Vesalian anatomy. My intention is to explore the production and use of an extremely popular work of renaissance medicine. While De ossibus came to the attention of sixteenthcentury physicians as a result of the humanist program of recovering the works of Galen from Greek manuscripts, it quickly took on a wide variety of roles, including being a teaching text and a source of controversy.

\section{De ossibus: A Successful Medical Text}

The earliest extant copy of De ossibus is a ninth-century Greek manuscript in Florence from which the first sixteenth-century Latin translation was made ${ }^{3}$. The work consists of an introduction and twenty-five chapters discussing the bones of the body from head to toe. In the introduction, Galen emphasised that knowledge of the bones is necessary for physicians treating fractures and dislocations, and he also introduced a number of terms and categories. First, he identified two broad categories of bones - one large and filled with cavities, and the other small and solid with no marrow - and then described and named the various forms of growths, or processes that occurred at the end of some of the large bones. Galen then announced that it would be useful to explain the terms he would use, beginning with the word skeleton, which he defined as all of the bones together, referring to books by unnamed authors with the title On the Skeleton. This was followed by a detailed discussion of the names and types of joints.

Following the introduction, the first six chapters, many of them quite short, are devoted to various aspects of the bones of the skull (including the teeth). Here, Galen covered topics like the cranial sutures, pores that allowed the flow of fluid from the brain to the nostril, the number and shape of the bones of skull, jaw, and so on. The neck, spine, vertebrae, sacrum, and coccyx took another four chapters to explain. The next seven chapters covered the bones associated with the thorax (including the sternum and ribs), and the remaining chapters were devoted to the arms, legs, hands, and feet ${ }^{4}$.

De ossibus was first printed in the sixteenth century by Antonio Blado in a Latin translation made by Ferdinandus Balamius, papal physician to both Leo X and Clement $\mathrm{VII}^{5}$. In the introduction to his translation, Balamius noted that Clement VII gave him the Greek manuscript to translate soon after it was found in a library in Florence ${ }^{6}$. The translation was printed in Rome in 1535 and re-printed, shortly thereafter, in Lyon by Melchior and Gaspar Trechsel, and then a third time in Paris, still in 1535, by Christian Wechel. Balamius's translation formed the basis for most of the Latin editions printed in the sixteenth century. It was extensively edited by Jacobus Sylvius in the 1540s, and translations were also made by other scholars, in both Latin and French.

In 1536, Balamius's translation was included in an edition of translated works by Galen published by Andreas Cratander in Basle. The 1538 Basle edition of Galen's Opera Omina in Greek, also organised by Cratander, included Balamius's Latin translation of De ossibus as well, presumably because Cratander lacked access to the Greek manuscript ${ }^{7}$. In the same year, a standalone edition of Balamius's De ossibus was printed in Venice by Bernardinum Stagninum, making six printings of the work in the three years between 1535 and 1538. 
7 The number of editions grew steadily in the 1540s. Balamius's De ossibus was included in the Juntine edition of Galen's Opera omnia of $1541^{8}$. A French translation was made by Jean Canape and printed in Lyon, also in 1541, and re-printed in Paris in the same year (Canape's translation was also reprinted in 1558, 1583, and 1588). As he noted in his introduction to the work, Canape made the translation as part of a broader program to educate French surgeons who could not read Latin or Greek. This program included translations of various works by Galen, Hippocrates, Paul of Aegina, and others and was carried out in the face of opposition from some members of the medical faculty at Paris who preferred to draw sharp lines between themselves and surgeons and barbers based in part on Latin literacy. Despite this view, the popularity of Canape's translations is obvious 9 .

8 In his introduction, Canape cited Galen's On Anatomical Procedures to support both the importance of anatomical knowledge for surgeons and that the bones were the first parts of the body a surgeon should learn. Aside from such introductory remarks, however, he supplied no details to his translation, which he presumably made from Balamius's Latin text (the title page noted that the translation was from Latin).

A Greek version of De ossibus (derived from a different manuscript than the one used by Balamius) first appeared in print in 1543, in the edition of Galen's Opera omnia edited by Martinus Gregorius and printed in Paris. ${ }^{10}$ Five more editions in Latin translation were printed in Paris between 1546 and 1549. Jacobus Gazellus printed Balamius's translation in 1546 in conjunction with Joannes Barbaeus, and then printed another on his own in 1548. That same year also saw an edition from Christian Wechel in Paris, and in 1549 Gazellus's widow released yet another edition that included a commentary Jacobus Sylvius, Andreas Vesalius's former teacher at Paris and a critic of his work. In addition to commenting on Galen's text, Sylvius also edited Balamius's translation extensively enough to make his version readily distinguishable from the 1535 original. Another edition of Balamius's translation was printed in 1549 by Guillaume Rouille.

The flurry of Latin editions printed in Paris in the 1540s by Gazellus and others was more than likely in response to a particular demand. Wechel had already printed an edition in 1535 and his decision to print another shortly after two editions by Jacobus Gazellus suggests that the book was selling well, especially given that two more editions were soon after issued by Gazellus and Guillaume Rouille. The most likely source for such demand seems to be the medical students of Paris. Jacobus Sylvius, who taught at Paris, was interested enough in the work to write a commentary on it and carefully rework its Latin translation.

11 Rouille printed De ossibus again in 1551 in a volume that included other works by Galen. This time he used Sylvius's version of the translation but did not include his commentary. The second Juntine edition was printed in 1550. In 1555, a version of De ossibus with Sylvius's commentary was printed in Paris and again in 1556. De ossibus was also printed in Valencia in 1556 with a commentary by Luis Collado, and 1556 also saw the third Juntine edition. A Greek edition of Galen's Opera omnia, edited by John Caius and printed in Basle in 1557, also included De ossibus - this time based on the Florence manuscript used by Balamius. ${ }^{11} 1558$ saw the re-print of Canape's French translation.

12 Although the 1550s were the peak years for editions of De ossibus, the book continued to attract attention and new translations were made. A new French translation by Jean Loine was printed in Orleans in 1561 by Éloy Gibier. Loïne's translation was different from Canape's in a number of ways. Not only did it include a French translation of the 
commentary made by Sylvius with its remarks about Vesalius and the infallibility of Galen (see below), but it also indicated that Loïne had translated De ossibus from Greek rather than from Latin as Canape had. Nevertheless, Loïne's purpose for making the translation seems to have been the same as Canape's, and he clearly had surgeons in mind. After his dedicatory letter, he included a brief poem addressed to the surgeon apprentices who were meant to read the text. In the first three lines, Loïne traced the history of the subject matter of De ossibus from Homer to Galen to Sylvius, making it clear that his work was supportive of the latter. A second poem written by Loïne was dedicated to Richard Hubert, master surgeon of Paris, another reinforcement of his intended audience. Although it was not as popular as Canape's, Loïne's translation was re-printed twice in the sixteenth century, in 1565 and $1571^{12}$.

13 A Latin version with Sylvius's commentary was also printed in Paris in 1561. 1565 saw another Juntine edition as well as another printing of Loine's French translation. In 1570, a work by Gabriele Falloppio purporting to be his exposition on De ossibus, although not containing the original text by Galen, was published posthumously by a former student. In 1571, Loine's French translation was printed for a third time.

14 A new Latin translation by Johannes Franciscus was published in Copenhagen in 1579. Franciscus, who taught at Copenhagen, altered the title slightly to On the bones for beginning physicians (ad tyrones medicos). He introduced the text with a description of the various works taught to medical students in which he included mathematics and botany. He described De ossibus as a foundational text, saying that just as in geometry one needed to know points, lines, and planes, likewise in medicine one needed to know the bones. At the beginning and end of the book were printed the same illustration of a standing skeleton, copied directly from Vesalius's Fabrica, which Franciscus attributed to Tobias Gemperlini ${ }^{13}$.

15 Another Greek edition of De ossibus was printed in Wittenberg in 1579, edited by Salomon Alberti. Durling notes that it was accompanied by a Latin translation ${ }^{14}$. In the 1580s, the Canappe French translation was printed twice more. There was another Juntine edition in 1597, and in 1599, a Latin edition by Johannes Sigfridus was printed in Helmeted. I have not been able to consult this work to determine whether it was a new translation ${ }^{15}$.

The majority of the editions of De ossibus in the sixteenth century were printed in France, mostly Paris and Lyon. The other two main centres of publication, Italy and Basle, were far less active, producing only a handful of copies each - largely as part of collected works of Galen. The majority of the printed editions were also in Latin, with French coming a distant second and Greek last. That De ossibus was a brief but comprehensive work written for beginners that also addressed a fundamental anatomical topic of interest to physicians and surgeons partly explains its popularity. We have seen indications that the book was being used in teaching medical students for instance, the remarks by Vesalius about using it in his demonstration at Bolognaand it was certainly part of the program of educating surgeons in Paris as well, but editions of De ossibus played various roles. In its early form, it represented a frequently printed, illustrated work on anatomy. 


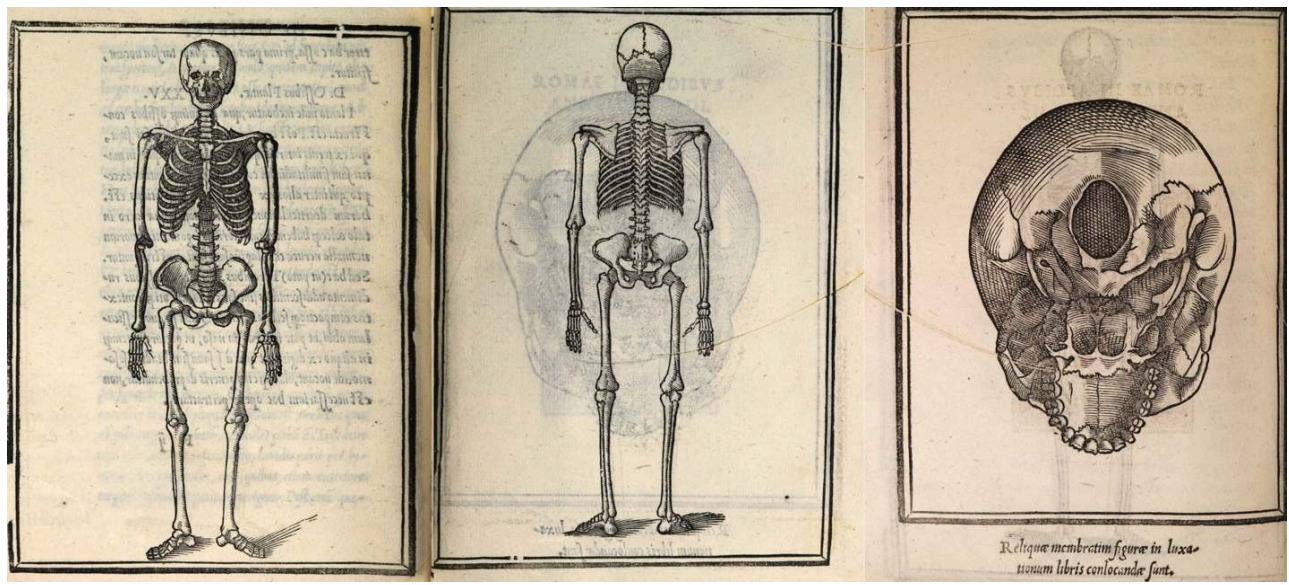

The illustrations from the 1535 Rome Edition courtesy Bayerische Staatsbibliothek

The first edition of De ossibus, printed in Rome in 1535, included three illustrations-two views of a complete skeleton, from the front and from the back, and an image of the underside of the skull with the lower jaw removed. These illustrations were included in a number of subsequent editions through the middle of the century. Aside from the Copenhagen translation of 1579 , which included the iconic image from Vesalius's Fabrica of a skeleton examining a human skull, no other images were included with the work and illustrated editions stopped after 1551.

By 1535 , other anatomical images had already appeared in print, and skeletons were a common theme. Berengario da Carpi included skeleton images in his 1521 anatomical text and in its abbreviated summary, the Isagoge Brevis, which appeared a year later. A skeleton was also featured in the surgical text of Hans von Gersdorff printed in 1517. Both of these works also contained images depicting the head separately, but the image of the skull in De ossibus was much different. While the images in Berengario and Gersdorff were focused on the top of the skull, the image in De ossibus was of the underside with the lower jaw removed.

None of the editions of De ossibus provided any detailed references in the text to the images they included. Galen had made no reference to images in his work, and, as Jacobus Sylvius would later argue in connection with his criticism of the Fabrica, in some works he actually seemed to disparage their use (see below). The 1535 Rome edition, where the images first appeared, was printed by Antonio Blado. By 1535 he was an important printer, and had already printed several illustrated texts on a number of subjects - it may thus have partially been his influence that led to illustrations in the first De ossibus.

The Lyon edition re-drew the images found in the Rome version. The new versions of the skeleton were set in a landscape, a common technique in early sixteenth-century printed anatomies. The posterior view also included a separate skull lying on the ground at the feet of the skeleton that was absent in the Rome version. The Lyon images were arguably not as well executed, and the underside of the skull lacked the same depth and shading and included fewer teeth than specified by Galen in the text.

The third edition from 1535, printed in Paris, did not include any illustrations at all, but they re-appeared in Cratander's Latin collection of 1536 and in the 1538 Greek collection as well. The images in Cratander's two editions were different from both the 
Rome and Lyon versions, and their order was changed so that the underside of the skull came before the two skeleton images rather than after. In the 1536 edition, the landscapes included in the 1535 Lyon version of the skeletons were removed (along with the additional skull), and a hatching pattern on one side of the skull in the frontal view of the skeleton, which was subtle in the 1535 Rome copy and overdone in the 1535 Lyon version, appeared to be copied in Cratander's version as an actual opening in the skull, albeit on the opposite side. The image of the underside of the skull in the 1536 edition depicted many more teeth than either Lyon or Rome (and more than specified by Galen who correctly stated that there were 16 teeth in the upper part of the mouth).

Illustration 2

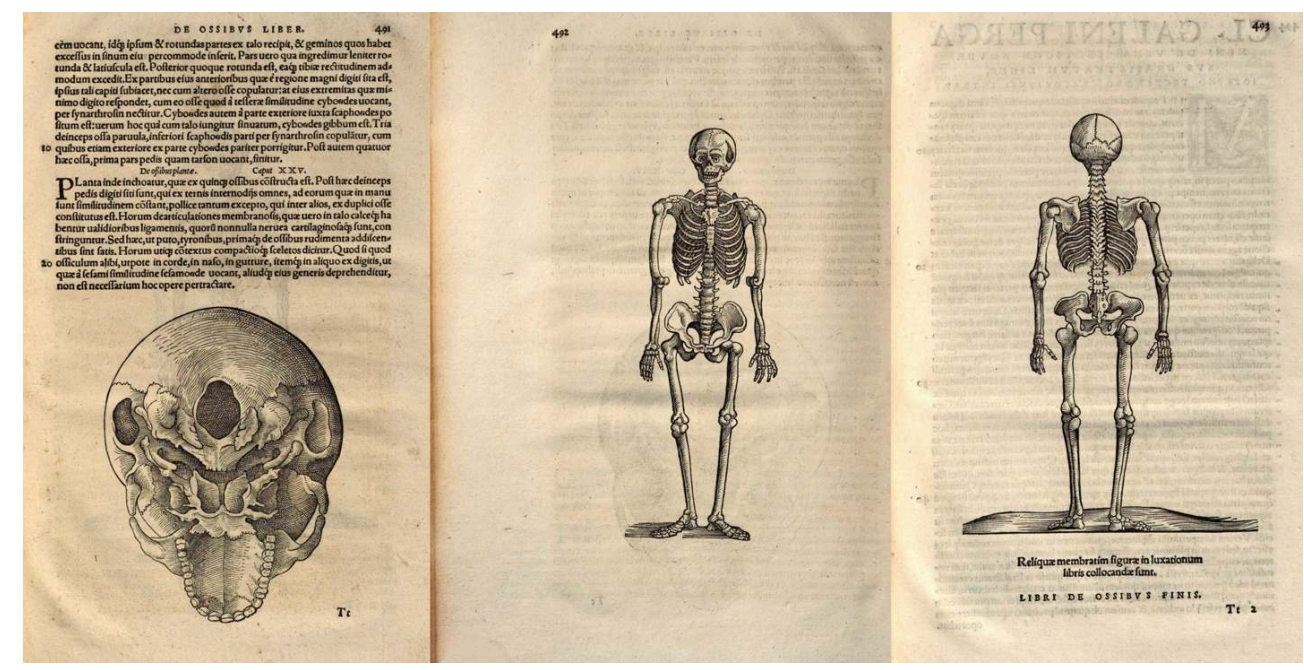

The 1536 Cratander Illustrations courtesy Bayerische Staatsbibliothek

The 1538 Greek version of De ossibu included the three images arranged differently. While the image of the underside of the skull still came before the skeleton, and all three images resembled the ones used by Cratander in 1536 in other ways, this time the two views of the skeleton were set side-by-side in the same illustration. The same mark depicting an actual opening on the side of the skull in the forward-facing skeleton and the same extra teeth in underside view of the skull were also apparent.

The 1541 Juntine Galen also included the illustrations for De ossibus re-drawn again but more closely resembling Cratander's version in style and order than the two 1535 copies. The underside of the skull included in the Juntine Galen was the most detailed and textured of all of them up to that point, but in 1543, Vesalius's Fabrica also included an image of the underside of the skull that closely resembled the images found in the editions of De ossibus that appeared before it. Vesalius included the image twice in Book 1 in order to reinforce different structures. Like most of the illustrations of the Fabrica, the image was a much higher quality than what had appeared in print previously. The artist tilted the skull slightly, which highlighted the zygomatic arch, and helped to demonstrate how differently that structure was drawn than it had been. In all of the previous De ossibus illustrations, the zygomatic arch (essentially the cheek bone) had been shown as two pieces with a large gap between them, but the Fabrica displayed it more accurately as two bones sutured together with no gap. Vesalius's skull image also included the correct number of teeth (sixteen). 

Some of the uptick in editions of De ossibus in the 1550s had to do with reactions to Andreas Vesalius's De humani corporis fabrica, which first appeared in 1543. In the Fabrica, Vesalius questioned Galen's authority and accused him of confusing animal and human anatomy. The bones played a prominent role in his claims. In Book I of the Fabrica (devoted to osteology), Vesalius made numerous references to mistakes by Galen and included a summary of the ways he disagreed with Galen's accounts of various aspects of the bones at the end of both Chapter 4 (On the joints) and Chapter 9 (On the bones of the upper jaw). He also devoted a passage to the description of how those who attributed human anatomy to Galen did him a disservice in Chapter 18 (On the sacrum and coccyx), and to a discussion of the mistakes other anatomists made in supporting Galen in Chapter 20 (On the heart bone) ${ }^{17}$.

27 Vesalius accused Balamius of deliberately blocking his access to the Greek manuscript of De ossibus, but it was clear that he was familiar with the work, presumably from its Latin translation, since he referred to it frequently in the Fabrica ${ }^{18}$. Passages from De ossibus figured in a number of his criticisms of Galen's osteology, including the summary in Chapter 9 and the exposition of the mistakes of those who attributed human anatomy to Galen mentioned above. Vesalius also referred to teaching from $D e$ ossibus in his demonstrations at Bologna in 1540, where he was known to make use of a variety of contemporary texts ${ }^{19}$.

It is beyond the scope of this article to examine all the specific issues Vesalius found with Galen's account of the bones, but it is useful to identify a few ideas he raised in order to understand what others discussed later. Vesalius took exception with Galen's naming and categorisation system for the joints. To clarify his own categorisation, he 
provided a summary of the terms and their meaning in a dichotomous diagram or table - an idea subsequently adopted by later commentators on De ossibus ${ }^{20}$.

Vesalius also disputed specific aspects of Galen's account of the structure of the bones of the upper jaw, the relative sizes of the humerus and tibia, and his claim that perforations in the skull allowed cerebral pituita to drain from the brain to the nostrils. He also disagreed with Galen's account of the number of bones involved in the sacrum and coccyx. Most of these structural issues, apart from the perforations in the skull, involved the differences Vesalius had observed between the bones of humans and the bones of animals, particularly apes and dogs, which led him to state that Galen had never worked with human bodies.

Vesalius emphasised that he had made his discoveries in part through direct experience with human bones, recounting various ways he had acquired that experience including when, as a student at Paris, he and a fellow student practiced identifying bones in a cemetery until they could do so blindfolded. They were forced to do so, Vesalius recalled, because they lacked a qualified teacher ${ }^{21}$.

In his commentary on De ossibus, Sylvius countered Vesalius's assertions by maintaining that Galen had in fact written about humans, not animals. He claimed he had often demonstrated this to his students "from nature's account and many skeletons" ${ }^{22}$. It is hard to escape the pointed reference here, given that one of Sylvius's students was Vesalius himself. Sylvius reinforced the point by noting that anyone who might have been interested in studying bones could have come to his home where he might see and touch all those things he described, another dig at Vesalius's claim that he had to go to cemeteries with his fellow student to study bones because he did not have a qualified teacher ${ }^{23}$.

When it came to Vesalius's anatomical claims, Sylvius re-affirmed the assertions made by Galen and disputed by Vesalius: the existence of the passage in the skull through which the pituita discharged, the number of bones in the upper jaw, sacrum and coccyx and the size of the tibia and humerus. He supported his arguments in passages that mixed condemnations of Vesalius, praise for Galen, and references to direct experiences. Sylvius went on to dispute more of Vesalius's claims in 1551 when he published a more comprehensive, and strident, condemnation of the Fabrica, the Veasani cuiusdam calumniarum hippocratis galenique.

Part of Sylvius's attack on Vesalius rested on his claims about direct examination of bodies. In the Veasani, for example, he offered detailed advice on the methods of examining the skull in order to find the openings for the pituita. One should blow into the skull to demonstrate the passage of the air through the openings, insert probes into them, or pour water through them. It was important that the skull was still warm or reheated and from a fresh cadaver ${ }^{24}$.

34 Sylvius also objected to the use of illustrations in his commentary and in the Veasani. He remarked in the commentary, for example, that he was unwilling to include illustrations because it was so easy for anyone to study the actual bones and then referred to illustrations of the bones that were both out of proportion and obscured by shading. Vesalius's biographer, C.D. O'Malley, has assumed that Sylvius was referring to the illustrations in the Fabrica given the general direction of his attack, but he may also have had the less sophisticated illustrations found in some editions of De ossibus in $\operatorname{mind}^{25}$. 
Sylvius's commentary on De ossibus was re-printed in 1555,1556 , and $1561^{26}$. It seems likely that a good deal of its popularity involved Sylvius's remarks about Vesalius and the Fabrica, which prompted a number of responses. In 1555, the same year that the second edition of Sylvius's version of De ossibus was printed, Renatus Henerus published a defence of Vesalius against Sylvius, and the Spanish anatomist, Luis Collado, defended Vesalius in his own edition of De ossibus ${ }^{27}$.

Despite his claim in the introduction that Sylvius had corrupted Galen's words through errors and omissions, Collado used Sylvius's edited version of the Latin translation of De ossibus for his commentary rather than Balamius's original. Along with his commentary, Collado also included a separate short summary of the reasons why he defended Vesalius against Sylvius in the form of a letter and an original short work devoted to the external foramina of the body in his edition. There is no question that Collado's main intention in writing the work was to support Vesalius, but his commentary was extensive one, drawing from a number of sources and ranging through topics well beyond the immediate contentions raised by Sylvius ${ }^{28}$.

Collado began his comments with a clear statement that Galen had written about the bones of apes, dogs, and other animals, that Vesalius had discovered the mistakes he made in doing so, and that Sylvius had misguidedly defended Galen. He then commented heavily on the introductory passages of De ossibus, providing short excerpts from Galen followed by pages of remarks of his own. Near the end of this string of comments, Collado, like Vesalius, also provided a dichotomous diagram of the proper categorization of the types of joints found in the body ${ }^{29}$.

In his introductory comments and in each subsequent chapter of De ossibus, Collado provided material from a wide range of sources, not only works by Galen, but also by Hippocrates, Celsus, and others. He pointed out those passages by Galen where the material touched on topics where Sylvius had attacked Vesalius, generally defending the Fabrica with statements to the effect that Vesalius had demonstrated the truth of the matter, but sometimes invoking other authorities as well. When Collado pointed out the mistake Galen and Sylvius had made concerning the cerebral pituita draining from the brain to the nostrils, for example, he not only cited Vesalius but also Leonhart Fuchs, who had published his own epitome of Vesalian anatomy in $1551^{30}$.

Collado also invoked his personal experience with dissections. In addition to relying on that experience to defend Vesalius, he occasionally used it to dispute him. He referred to his personal experience in challenging Vesalius's descriptions of certain bones of the head, for example, and he modified Vesalius's descriptions of the bones in the ear (which he claimed to have discovered) ${ }^{31}$.

The dispute between Sylvius and Vesalius produced additional literature in the sixteenth century. Renatus Henerus also published a work in defence of Vesalius's claims $^{32}$. Rodriguez de Guevara defended Vesalius's writings on bones in the introduction to his 1559 anatomical text that was paradoxically devoted to defending Galenic anatomy ${ }^{33}$. Realdo Colombo was dismissive of both Vesalius and Galen in his anatomical text and made his own claims about knowledge of osteology, and other authors contributed to the debate $\mathrm{e}^{34}$.

One of Vesalius's successors at Padua, Gabrielle Falloppio, also supplied remarks on De ossibus. During his lifetime, Falloppio had written a book of anatomical observations that supported the new Vesalian anatomy while making some corrections to the 
material in the Fabrica - to which Vesalius responded positively. In 1570, after his death, one of Falloppio's students, Francisco Michino, published what he reported to be Falloppio's exposition on Galen's De ossibus. The text he printed was not an actual commentary, but was rather Falloppio's own teachings and it included more than just material on bones, beginning with several chapters devoted to broad remarks about anatomy in general. Nevertheless, once he turned to the bones, Falloppio followed Galen's De ossibus closely. Like Vesalius and Collado, Falloppio also included a dichotomous diagram of the joints in his book ${ }^{35}$.

of the various anatomical works by or attributed to Galen that were printed in the sixteenth century, De ossibus was by the far the most popular. On Anatomical Procedures, another work recovered in the sixteenth century, was printed less than a dozen times, as were the various works on specific parts of the body by Galen ${ }^{36}$. The initial appearance of De ossibus in 1535 certainly sparked the re-prints that moved the work from Rome towards the active translation program by medical humanists in France, where the work would have a wide appeal. From there, it was incorporated into compilations of Galen's works published soon after. Its printing in France was also useful for Canape when he compiled his French translations of Galen for the use of surgeons.

43 The popularity of Galen's De ossibus in the second half of the sixteenth century was due in part to the way it served as a vehicle for reactions to Vesalian anatomy. The challenge issued by Sylvius's commentary sparked a number of reactions. The book also continued to have value as a teaching text. The publication of Falloppio's discussion by one of his students reinforces this link between De ossibus and medical schools that we have seen throughout this discussion: from Vesalius's own references to using it at Bologna, to his teacher's reactions; from its role in teaching surgeons, to the way Johannes Sigfridus saw its place in the medical curriculum (and his subtle changing of the title). While the work had appeal to humanist scholars interested in restoring the Greek Galenic corpus, it was also an early example of illustrated, printed anatomical texts. Its continued utility as a teaching text, originally designed for students, may have been its most popular feature.

Many of the issues that prompted the various commentaries and editions we have seen here continued to play a role in the reception of De ossibus beyond the sixteenth century. As late as 1665 , Joannis van Horne, who taught anatomy at Leiden, produced a compilation of material focused on De ossibus that he called Controversia de ossibus, a book that neatly encapsulates how Galen's introductory text on the bones could prompt so much additional material.

After reviewing the printed history of De ossibus, which had continued in the seventeenth century, van Horne noted the difficulties associated with the terminology used by Galen to describe the bones and the translation of his Greek words into Latin. To help clarify things, van Horne supplied a side-by-side, Latin and Greek rendering of the text in which the Latin included specific Greek terms along with their Latin equivalents. He also included careful notes at the end of the work where he attempted to clarify specific passages. Having established the linguistic aspects of De ossibus, van Horne moved on to the anatomical issues found in Galen's account of the bones by compiling the comments of Sylvius, Henerus, Bartolomio Eusachio, and Vesalius about what Galen said in straightforward, numbered lists cross referenced to each other. The book ended with passages devoted to the bones from Hippocrates and Celsus. Like 
Galen's De ossibus, the material from Hippocrates was also supplied in both Greek and Latin $^{37}$.

Like Vesalius before him, van Horne was a dissector with a humanist's interest in the linguistic issues that came when recovering Greek medical knowledge and translating it into Latin. De ossibus was a perfect vehicle for combining these interests: humanism, translation, and experiment. It contained tricky linguistic questions about the classification and naming of joints, and a straightforward account of a single aspect of anatomy that could be carefully checked in the body itself. Galen's mixing of animal and human bodies supplied an interesting controversy, while his simple, organised discussion made his book a useful teaching text regardless of whether you accepted that he had made mistakes or not. As Galen himself pointed out, the bones were the basic structure on which the body was built, and knowledge of them a first priority for the medical student. All of these factors contributed to a widespread and ongoing interest in Galen's work in the renaissance.

\section{NOTES}

1. Richard J. Durling, "A Chronological Census of Renaissance Editions and Translations of Galen", Journal of the Warburg and Courtauld Institutes, vol. XXIV, n 3-4, Jul.- Dec., 1961, p. 288 lists twentyfive editions of the work. Additional editions are described in Ivan Garofalo \& Armelle Debru (eds), Galien, tome VII. Les os pour les débutants. L'anatomie des muscles, Paris, Les Belles Lettres, 2005, p.9, in Gerhard von Fichtner, Corpus Galnicum. Bibliographie der galenischen und pseudogalenischen, Berlin, Akademie der Wissenschaften, 2019, p. 19, and in the Galeno. Catalogo delle Traduzioni Latine http://www.galenolatino.com/index.php?id=10\&L=\&uid=23.

2. For a summary of this view of Galen's fate in the sixteenth century and a discussion for doubting it see Vivian Nutton, "Renaissance Galenism, 1540-1640: Flexibility or an Increasing Irrelevance?" in Petros Bouras-Vallianatos \& Barbara Zipser (eds), Brill's Companion to the Reception of Galen, Leiden, Brill, 2019, p. 472-486.

3. Ivan Garofalo \& Armelle Debru, op. cit., p. 9.

4. Charles Singer, "Galen's elementary course on bones", Proceedings of the Royal Society of Medicine, vol. XLV-11, 1952, p. 767-776 provides an overview of the text as well as an English translation.

5. Paola Zambelli, "Balami, Ferdinando" in Dizionario Biografico degli Italiani, Padua, Enciclopedia Italiana, 1963, p. 36.

6. Ferdinandus Balamius, Siculus, Galenus de ossibus. Ferdinando Balamio Siculo interprete, Antonio Blado, Rome, 1535, p. sig Aiir-v.

7. Vivian Nutton, John Caius and the Manuscripts of Galen, Cambridge, The Cambridge Philological Society, 1987, p. 44.

8. For the Juntine editions see Stefania Fortuna, «Editions and Translations of Galen from 1490 to 1540» in Editors: Petros Bouras-Vallianatos and Barbara Zipser, Brill's Companion to the Reception of Galen, Leiden, Brill, 2019, p. 446-449.

9. Jean Canape, L'anatomie des os du corps humain. Autheur Galien. Novellement tradicte de Latin en francoys, par monsieur maistre Jehan Canappe Doteur en Medicine, Charles Estienne, Lyon, 1541, p. 3-8. For a useful overview of Canape's program see Vivian Nutton, "Humanist surgery", in A. Wear, 
R.K. French, I. M. Lonie (eds), The Medical Renaissance of the Sixteenth Century, Cambridge University Press, Cambridge, 1985, p. 83-85.

10. Ivan Garofalo \& Armelle Debru, op. cit., p. 30 and Vivian Nutton, John Caius, op. cit., p. 66, n. 9.

11. Vivian Nutton, John Caius, op. cit., p. 106.

12. Jeann Loïne, Le Livre des oz de Cl. Galen aux apprents en medicine... Éloy Gibier, Orleans, 1561 . The fact that Loïne translated from Greek is in the Royal Privilege that follows the title page.

13. Joahnnes Franciscus, Clavd. Galeni de ossibvs ad tyrones medicos liber, Copenhagen, Laurentius Benedicti, 1579, A3v.

14. Richard J. Durling, op. cit., p. 277.

15. Johannes Sigfridus, Cl. Galeni De Ossibus Ad Tyrones Liber, Lucius, Helmstedt, 1599. This editioin is not in Durling, op. cit.

16. Ivan Garofalo \& Armelle Debru (eds), op. cit., p. 32-33.

17. Andreas Vesalius, De humani corporis fabrica libri septem, Frobin, Basle, 1543, Book 1, p. 16-17, $42,85,94$.

18. Ibid, p. 42.

19. Ibid, p. 27.

20. Ibid, p. 12.

21. See Charles Donald O'Malley, Andreas Vesalius of Brussels. 1514-1564, Los Angeles, University of California Press, 1964, p. 289-296.

22. Ibid, p. 238.

23. See R. Allen Shotwell, "Animals, Pictures and Skeletons", Journal of the History of Medicine and Allied Sciences, vol. LXXI-1, January 2016, p. 815-817.

24. Jacobus Sylvius, Vaesani cuiusdam calumniarum in Hippocratis Galenique rem anatomicam depulsio, Paris, Jacobi Gazelli, 1551, p. 4v.

25. Charles Donald O'Malley, op. cit., p. 239.

26. Richard J. Durling, op. cit., p. 271-274

27. On Collado see José M. López Piñero, “The Faculty of Medicine of Valencia: Its Position in Renaissance", in Mordechai Feingold \& Victor Navarro-Brotons (eds), Universities and Science in the Early Modern Period, Springer, New York, 2006, p. 65-82. José M. López Piñero, “The Vesalian Movement in Sixteenth-Century Spain", Journal of the History of Biology, vol. XII-1, 1979, p. 45-81.

28. Luis Collado, CL. Galeni Pegameni liber de ossibus ad tyrones interprete Ferdinando Balamio, Enarratore Ludovico Collado medico, Valencia, Johannis Flandri, 1555.

29. Ibid, p. $4 \mathrm{r}-20 \mathrm{v}$

30. Ibid, p. 27

31. Ibid, p. 30 and José M. López Piñero, op. cit., p. 72.

32. Renatus Henerus, Adversus Iacobi Sylvii de pulsio num anatomicarum calumnias, pro Andrea Vesalio apologia, Venice, 1555.

33. See Bjørn Okholm Skaarup, Anatomy and Anatomists in Early Modern Spain, Ashgate, Farnham, 2015, p. 94 and p. 243-244.

34. Charles Donald O'Malley, op. cit., p. 291.

35. Gabrielle Falloppio, Expositio in librum Galeni de ossibus, Venice, Simone Galignani, 1570, p. 23v.

36. Richard J. Durling, op. cit., p. 283.

37. Johannes van Horne, De ossibus: graece et latine: ex bibliotheca Joannis van Horne, Danielem vander Boxe, Leyde, Lugduni Batavorum, 1665. 


\section{ABSTRACTS}

This article examines the editions of Galen's De ossibus ad tirones (On Bones for Beginners) in Latin, Greek, and French printed in the sixteenth century - a period that saw more than two-dozen printings of the book. After a brief survey of the contents of the book, a description of the various editions and translations produced is given. The illustrations included in the editions up through the middle of the century are then described, and finally the role the book played in a dispute between Andreas Vesalius and his former teacher, Jacobus Sylvius, is examined, including an edition of De ossibus written by the Spanish physician, Luis Collado.

Cet article examine les éditions du De ossibus ad tirones de Galen (Sur les os pour les débutants) en Latin, Grec et Français imprimés au XVI ${ }^{\mathrm{e}}$ siècle, période qui a vu plus de deux douzaines d'impressions du livre. Après un bref aperçu du contenu du livre, une description des différentes éditions et traductions produites est donnée. Les illustrations incluses dans les éditions jusqu'au milieu du siècle sont ensuite décrites, et enfin le rôle que le livre a joué dans un différend entre Andreas Vesalius et son ancien professeur, Jacobus Sylvius, est examiné, y compris une édition de De ossibus écrite par le médecin espagnol Luis Collado.

\section{INDEX}

Keywords: Galen, On Bones, anatomy, Vesalius, printing

Mots-clés: Galen, Sur Les Os, anatomie, Vésale, impression

\section{AUTHOR}

\section{R. ALLEN SHOTWELL}

Ivy Tech Community College 